Nataliia Andrusiak, Associate Professor, PhD in Economics (Candidate of Economic Sciences) Cherkassy National University named after BohdanKhmelnytsky, Cherkassy, Ukraine

\title{
Priority Areas of Development of Ecological and Economic Competitiveness of the Regions in the Developed Countries
}

\begin{abstract}
The article is devoted to the review of priority directions of ecological and economic competitiveness of the regions in some developed countries, are revealed ecological types of economic activity, which are preferred by the regions of these countries. It is substantiated that, under the current conditions of ecological and economic development, existing reserves of resources in the regions are not decisive for the development of specific industries; development depends on the latest scientific and technological products in a particular field. The production of environmentally neutral and friendly products allows many regions to reduce their dependency on non-renewable resources without reducing the efficiency of their economic performance. Priority directions of efficiency of development of ecological and economic competitiveness of the regions of the USA and Germany are investigated, and it is determined that the cluster system of organization of ecological productions is based on the ecological and economic activity of most regions in the developed countries.
\end{abstract}

Region, Environmental and Economic Competitiveness, World Experience, Ecological Products, National and Local Support, Cluster Cooperation

Н.А. Андрусяк, доц., канд. экон. наук

Черкасский нац̧иональный университет имени Богдана Хмельницкого, г. Черкассы, Украина

$\begin{array}{cccc}\text { Приоритетные } & \text { направления } & \text { развития } & \text { эколого-экономической } \\ \text { конкурентоспособности регионов развитых стран } & & \\ \text { Статья посвящена обзору приоритетных } & \text { направлений } & \text { эколого-экономической }\end{array}$
конкурентоспособности регионов в некоторых развитых странах, выявлены экологические виды экономической деятельности, которые предпочитают регионы этих стран. Обосновано, что в современных условиях эколого-экономического развития существующие запасы ресурсов в регионах не имеют решающего значения для развития конкретных отраслей; развитие зависит от новейших научных и технологических продуктов в конкретной области. Производство экологически нейтральных и дружественных продуктов позволяет многим регионам снизить свою зависимость от не возобновляемых ресурсов без снижения эффективности их экономических показателей. Исследованы приоритетные направления эффективности развития эколого-экономической конкурентоспособности регионов США и Германии, и определено, что кластерная система организации экологических производств основана на эколого-экономической деятельности большинства регионов развитых стран.

регион, экологическая и экономическая конкурентоспособность, мировой опыт, экологические продукты, национальная и местная поддержка, кластерное сотрудничество

Statement of the problem. An environmentally friendly development strategy in a multipolar world economic space emphasizes the necessity to agree approaches to national and subnational regulation of ecological economic systems with global experience and best practices. Forecasts for the further development of society emphasize that the rates and volumes of consumption of natural resources, the situation of the environment in the near future will be the main objective factors hindering the development of the domestic economy and its regions. The situation is complicated by the current political and economic state of our country, which has led to an aggravation of the environmental problem, reduction and slowing down of investment flows, which increases the ecological and economic risks against the background of high wear of equipment of the vast majority of industrial enterprises.

The development of regions is now accompanied by institutional constraints related to the inefficiency of the specification of ownership and resource allocation, budgetary constraints that are manifested in the lack of budget funding for regional environmental

(C) Nataliia Andrusiak, 2019 
programs, economic constraints caused by the inertia of introduction of advanced environmental protection technologies, and waste-free production, demographic constraints related to the aging of the population and the outflow of skilled labor caused by, among other things, environmental degradation. Thus, the dynamics of mesoeconomic indicators is largely determined by the natural resource potential of the regions, the ecological situation, and the level of effectiveness of environmental measures implemented by the authorities. In turn, the sustainable development of regional entities is aimed at improving the standard and quality of life of the population, of which one of the indicators is the environmental situation. Ensuring a sustainable trend in the progressive dynamics of social, economic and environmental indicators of the situation of the regions involves the development and implementation of an ecological economic-oriented strategy that takes into account the mutual impact of multivector development factors.

Analysis of recent researches and publications. In the fundamental studies based on a systematic approach to the analysis of society and nature, the special place is occupied by the works of foreign scientists -J. Lovelock [1] studied environmental systems, E. Leroy [2] studied the evolution of human development, T. de Chardin [3] summarized the concept of social production, V.I. Vernadsky [4] considered the nature of social systems, K.G. Hoffman [5] systematized the concept of economic assessment of natural resources etc. In general, theyinitiated the analysis of modern social production as an ecological and economic system. Despite the vast coverage of scientific publications on environmental and economic issues, there is insufficient of works ensuring the effectiveness of regional and economic competitiveness of regions in developed countries.

Paying attention to the number and soundness of scientific publications in this field, the issues of the priority of ecological and economic competitiveness of the regions in the developed countries have not been fully investigated due to the development of scientific and technological progress, power and diversity of ecological and economic transformations in the world and their consequences.

Statement of the objective. The purpose of the study is to determine the priority directions of development of ecological and economic competitiveness of the regions in developed countries.

The main material. The development of mankind is possible under the condition of constantly supported scientific and technological progress and the effective mechanism of pricing, as well as the reduction of consumption of the present generation. However, the implementation of this approach in practice is complicated by the limitation of natural resources, which may have non-market value consumer values, - biological diversity, life support systems, etc.

The world market of ecological products in terms of transformation of wind energy into energy available to mankind is formed by developed countries of Europe, USA, China, and India (Fig. 1). However, in terms of one person, its production will look like this (Fig. 2).

Regarding the ecological and economic competitiveness of the regions in these countries, it should be noted that its differentiation is generally insignificant, that is, if, for example, ecological and energy policy in some regions is successful, other regions of the country try to support this policy and produce products on the basis of cluster cooperation, which will further provide the development of energy technologies. 


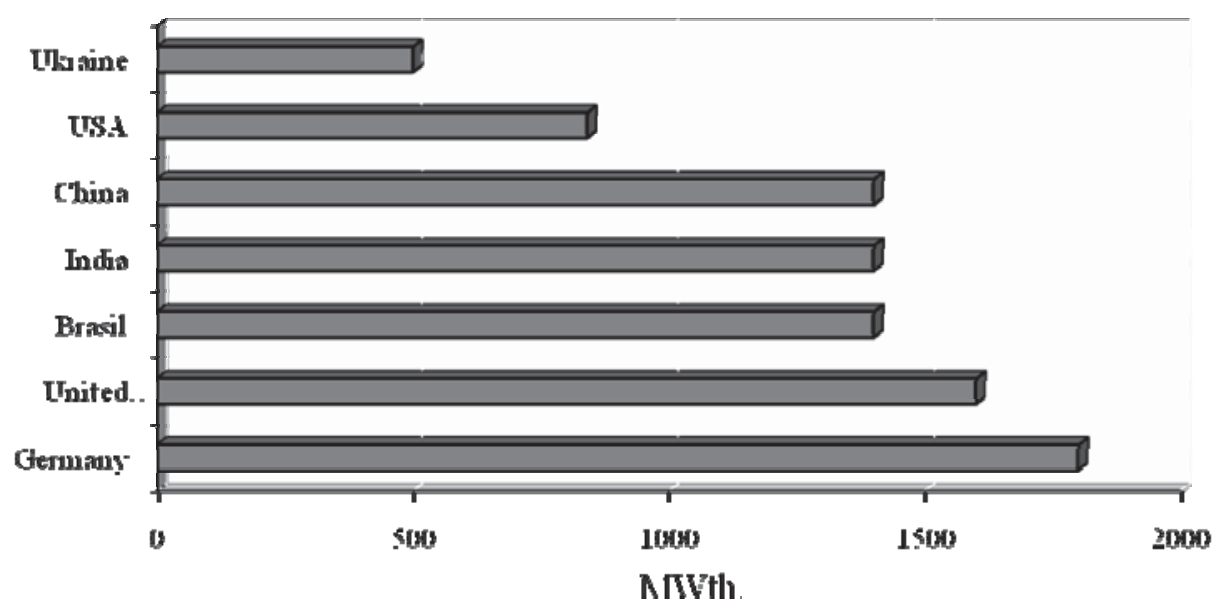

Figure 1 - Power of wind generating installations in selected countries of the world Source: developed by the author on the basis[6].

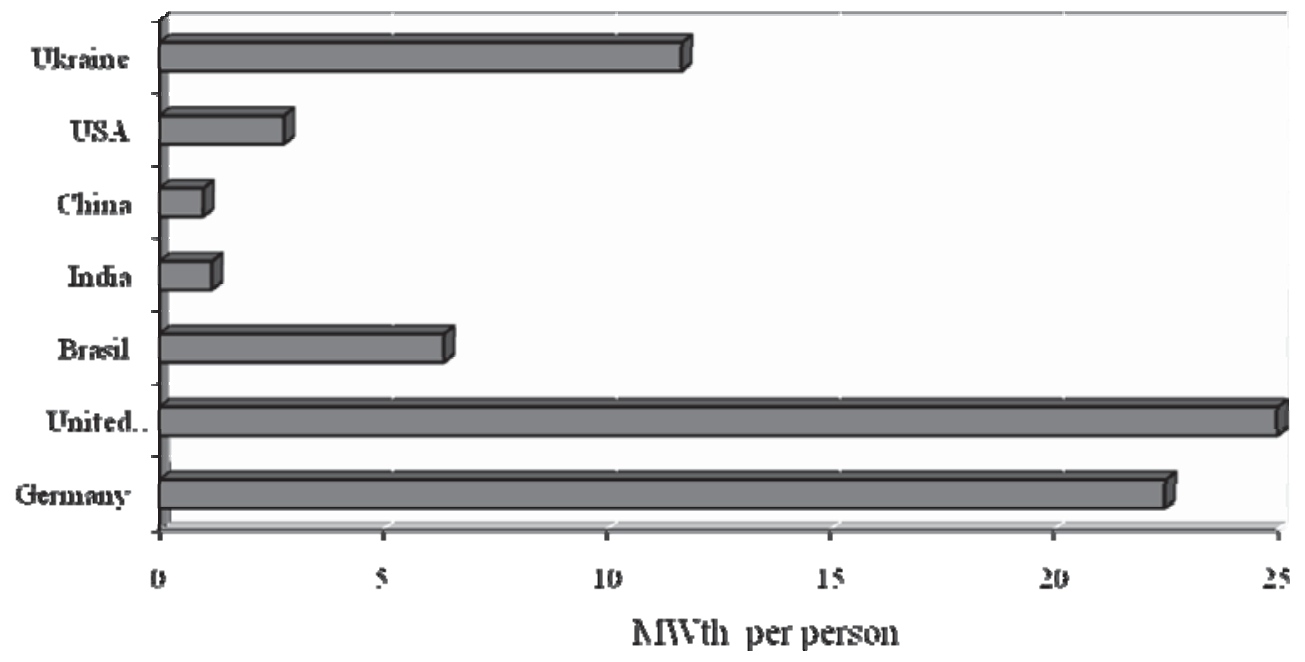

Figure 2 - Power of wind generating installations in terms per capita Source: developed by the author on the basis[6; 7].

Researches show that the energy sector is the most successful in demonstrating the environmental and economic competitiveness of individual regions of some countries. On this basis, we consider it advisable to study the indicators of the development of the energy industry in the US regions as a type of ecological products, the active production of which forms the ecological and economic competitiveness in the territories of this country.

Due to the technological development in the last decades, the prerequisites for replacing non-renewable energy resources are renewed. Gas, oil, and coal are losing its energy resources and obtain the different status, namely, raw materials for the recycle (chemical) industry.

Using the EIA (U.S. Energy Information Administration) data [8], we examine the impact of the environmental component on the economy of the US regions.

The proven reserves of oil and gas condensate are admitted states: Texas (26\% of the country's reserves), Alaska (24\%), and California (15.6\%). In shelf sediments, $14 \%$ of national oil reserves are concentrated, more than $4 / 5$ of these reserves belong to the Gulf of Mexico. The United States has the world's largest certified reserves of coal of all types. It is estimated total coal reserves in the US, that is 3.6 trillion tons, including those suitable for 
modern coal mining methods, 461 billion tons of coal (bituminous) coal and anthracites concentrated in the coal basins of the eastern and central part of the country: Pennsylvania, Ohio, West Virginia, Tennessee, Alabama, Illinois, Indiana [9, 191-197] (Table 1).

Table 1 - Selected indicators of energy natural resources and indicators of economic development of the US regions

\begin{tabular}{|l|c|c|c|c|c|c|c|}
\hline & $\begin{array}{c}\text { Energy } \\
\text { resources } \\
\text { reserves, } \\
\% \text { of } \\
\text { total } \\
\text { reserves }\end{array}$ & $\begin{array}{c}\text { Gross } \\
\text { energy } \\
\text { production, } \\
\text { trl. Btu }\end{array}$ & $\begin{array}{c}\text { Energy } \\
\text { production } \\
\text { per } \\
\text { capita,billi } \\
\text { on,Btu }\end{array}$ & $\begin{array}{c}\text { Internal } \\
\text { energy } \\
\text { use, trl. } \\
\text { Btu }\end{array}$ & $\begin{array}{c}\text { Internal } \\
\text { use of } \\
\text { energy } \\
\text { from the } \\
\text { volume } \\
\text { produced, } \\
\%\end{array}$ & $\begin{array}{c}\text { GRP, } \\
\text { billion } \\
\text { US } \\
\text { dollars }\end{array}$ & $\begin{array}{c}\text { GRP per } \\
\text { capita, } \\
\text { billion US } \\
\text { dollars }\end{array}$ \\
\hline Alaska & 24 & 600 & 0,83 & 228,4 & 38,1 & 46,9 & 64,9 \\
\hline Texas & 26 & 13183 & 0,51 & 6520 & 49,5 & 1482 & 57,7 \\
\hline California & 15 & 7830 & 0,21 & 3600 & 46,0 & 2317 & 61,5 \\
\hline $\begin{array}{l}\text { North } \\
\text { Dakota }\end{array}$ & 0,7 & 586 & 0,86 & 170 & 29,0 & 48,5 & 70,9 \\
\hline Colorado & 0,6 & 1484 & 0,29 & 490 & 33,0 & 292 & 57,1 \\
\hline
\end{tabular}

Source: developed by the author on the basis [9].

The annual review of US energy resources, based on which the table is made, concludes that, in the current environment of ecological and economic development, existing reserves of non-renewable energy resources in the regions are not decisive for the development of the energy industry. Thus, despite the scanty reserves of non-renewable resources in individual regions of the country (eg, Colorado, North Dakota), per capita energy production does not differ significantly from the energy-rich regions. This is primarily due to the use of the latest ("green") technologies for converting solar, wind, geothermal energy into electrical, thermal.

The production of environmentally neutral (non-destructive production and consumption) and environmentally-friendly (production and consumption of which have a positive environmental impact) allows many regions to reduce dependence on non-renewable resources without reducing the efficiency of economic performance. As an example is the North Dakota economy, which is characterized by wind farms manufacturing and installation, which is considered promising for the US, as the country has a long coastline and considerable wind resources. According to the research conducted by the University of Delaware, the true potential of wind power along the mid-Atlantic coast from the famous Cape Cod to New York can reach $330 \mathrm{GW}$ that is sufficient to provide electricity to all nine Mid-Atlantic States [10].

An important source of formation environmental and economic benefits for the US regions is an industry that almost only this country has formed and developed to such a high level. These are scientific and educational series that promote the environment of the regions, their nature, innovations in this field and, as a consequence, tourism, hotel and restaurant business. Thus, in 2017, the total revenue in the film industry amounted to $\$ 64$ billion, including \$12.9 billion (20\%) it is income from movie and TV about ecology, nature, etc. The use of this competitive advantage in the US regions is realized in annual tourist revenue of about $\$ 220.1$ billion. The most popular vacation of 2017 for American travelers, which is also the result of the effective use of the above mentioned competitive advantage, was a beach vacation, about $30 \%$ of American travelers said in surveys wishing to relax on a cruise, 
because such a vacation is most beneficial due to the excellent environmental situation of reservoirs. Today, the United States is the leading market for cruises in the world, compared to the second largest cruise ship market in Germany; the USA in 2017 had more than in five times the number of passengers on cruise ships. Overall, the travel and tourism industry is one of the largest industries in the United States, providing about \$1.5 trillion in GDP annually, is a reliable source of employment for the US residents, directly providing about 5.5 million workplaces annually. It is foreseen that by 2027 the industry should achieve more than \$2.6 trillion in revenues.

So, the priority areas for the effectiveness of the development of ecological and economic competitiveness of the US regions are based on the following provisions:

1) significant support and assistance from the state and local authorities for ecological innovations, which is implemented in the legislative framework (tax breaks, vacations, flexible tax rates, etc.);

2) minimal state interference in the process of formation and implementation of ecological and economic innovations;

3) financing of global environmental research is carried out at the expense of the state, all others, including those contributing to the formation of ecological and economic competitive advantages at the regional level, at the expense of the corporation and investors;

4) active involvement of scientific personnel from other countries and import of innovative ideas, their financing and implementation, ahead of other;

5) green energy production is directly linked to its steadily increasing consumption, which drives innovation in the industry; energy saving is not a priority for the state and its regions.

Ukraine has little potential for wind power development. The western and eastern coasts of Crimea, currently annexed, and the High Carpathians (part of the Chernivtsi and Ivano-Frankivsk regions) are promising regions for the development of this industry. The process of construction of the Ukrainian wind power industry began in 1996, when the Novoazovsk Wind Power Plant was designed with a capacity of 50 MW. In 1997 the Truskavets wind farm started working. By the end of 2017, the installed capacity of wind power plants (WPP) in Ukraine was $514 \mathrm{MW}(0.93 \%$ of the total generation capacity) [11].

The recalculation of the amount of energy produced per person shows that the leaders in wind power are the United Kingdom and Germany, which produce 25 and $22 \mathrm{~kW}$ per person. Contrary to popular belief, Ukraine also falls into the category of leaders, the amount of energy produced in which, due to environmental technologies, is amounted to $11 \mathrm{~kW}$ per person.

Insufficient amount of energy, raw materials and natural resources under the conditions of effective regulation of innovation processes allows carrying out successful economic activity taking advantage of geographical location, availability of water and other restorative resources. An example of gaining ecological and economic competitive advantage from such resources is the economy of the North Rhine-Westphalia (Germany). North RhineWestphalia is the most economically powerful region of the Federal Republic of Germany: in 2016, the region achieved a gross regional product of almost 670 billion Euros. As an independent administrative unit, North Rhine-Westphalia ranks 19th place among the largest economies in the world, between Turkey and Switzerland.

An important factor in the economic success of the North Rhine-Westphalia is its geographical location. There are two major European transport routes here: the north-south axis between south-west England and northern Italy and the west-east axis between Rotterdam and the dynamic countries of Eastern Europe. 140 million people live within a radius of 500 kilometers around the regional capital of Dusseldorf; it's almost $30 \%$ of European Union consumers. North Rhine-Westphalia has additional benefits, such as 
organized infrastructure, skilled workers and high quality commercial premises, which provides the highest concentration of scientific institutions in Europe (67 colleges, 14 Frauenhofer institutes, 12 Max Planck institutes and about 100 research institutes of universities).

The ecological and economic competitiveness of the North Rhine-Westphalia is ensured primarily by its geographical location. A significant part of environmental services (72.1\%), industrial development $(27.5 \%)$ makes it possible to provide production of $21 \%$ of the country's GDP with a small indicator of the region's population, is only $18 \%$ of Germany's total population. The value of GDP per capita in the period 2016-2017 was 39.7 thousand Euros, which is slightly less than the national average (42 thousand Euros) [12].

In contrast to the North Rhine-Westphalia, the other region of Germany, Bavaria, is one of the richest in minerals (mineral and energy) region of Germany, which creates for it significant environmental and economic competitive advantages. The analysis of the dynamics of the indicators of ecological and economic competitiveness of Bavaria was carried out using the materials of the website of the Ministry of Economy and Regional Development of the Land of Bavaria [13].

The economic basis of the Land of Bavaria is the dynamic development of the processing industry, energy, mechanical engineering, as evidenced by the value of the gross regional product of these industries in the GRP of the region. Thus, the share of industry in 2016-2017 reached 34.4\% in the GRP of the region, which is the largest indicator among other regions of Germany and is about 600 billion Euros, or 44.2 thousand Euros per person. Typical for this region is the reorientation of the industry towards the production of environmentally neutral and environmentally friendly products, especially in the field of energy supply. Since 2011, the share of renewable energy in gross electricity generation has increased by almost $40 \%$. Bavaria takes the first place in the country in the usage of hydropower, geothermal, solar and wind power, but the active production of energy from these resources forms a new system of challenges for the regional economy. One of these challenges is to create a reliable ecological and economic energy supply system. For that purpose, in Bavaria based on innovative technologies, systems of intelligent distribution networks and supra-regional electricity transportation are being created, as well as the capacity expansion of the networks. In order to improve the environmental situation in the region, gas power plants, decentralized cogeneration units are being built, and the systems of loading management and natural gas storage are being modified.

Increasing the capacity to produce and install renewable energy equipment is a priority value for enhancing the region's environmental and economic competitiveness. The share of renewable energy in gross electricity production reached $2,016 \mathrm{GW}$, or $43 \%$, which is more than two-thirds in comparison to 2010 year. Significant environmental and economic competitive advantages were generated by the construction of new wind turbines, making the region ranked 6th place in the nationwide ranking in 2016 [13].

Despite the favorable conditions for agricultural development, the Land of Bavaria does not produce enough agricultural products to meet its own needs. In fact, only livestock is developed. The amount of GRP at the expense of agriculture is 3.6 billion Euros $(0.7 \%)$.

Another environmental benefit of this region is its climatic and relief features. Tourism provides an income of about 600,000 people in Bavaria and is an important economic factor and generator of development in all sub-regions of Bavaria. This is one of the key elements for creating an equal living conditions in Bavaria and creating high quality workplaces. Tourism services in 2017 amounted to 104.2 billion Euros, or $18.2 \%$ of the Bavarian Land GRP, which amounted to 8.01 thousand Euros per person [13].

In some areas, the lack of natural resources adversely affects their ecological and economic competitiveness. Thus, according to the Ministry of Economy, Science and 
Statistics of the Land of Saxony-Anhald (Germany), indices of industrial development, services, transport, and construction are much lower than in the country as a whole. The gross value added index in the last decade is about 0.9 , services is about 0.95 , trade, transport, catering is about 0.8, information services is less than 0.4 , and only in agriculture and construction this index is higher than 1 (2.5 and 1.4 respectively). As a result, it has the lowest level of gross domestic income per person, that is 26.3 thousand Euros in 2017 [14].

At the same time, favorable agro-ecological conditions in the region create the preconditions for increasing the ecological and economic competitiveness in the field of agriculture. The Land Saxony-Anhald is the only region in Germany where there is an excess of agricultural exports over imports. In order to increase the ecological and economic competitiveness of the region, a local program "The Future of the Food and Agriculture Market"is in force that aims to develop production of organic food in the region, which includes all the stages, from cultivation to the final product. The investment in this project during 2012-2017 amounts to more than 5 billion Euros due to the subsidies of the federal budget. This program has led to an increasing in the level of gross regional income per person from 19.8 billion Euros in 2011 to 26.3 thousand Euros in 2017 [15].

The implementation of the "Future Chemistry and Bioeconomics" program, with a budget of 1.2 billion Euros per year, envisages the usage of agricultural residues to produce bioethanol as an alternative fuel, contributing to the growth of gross regional income in 2017. For example, a bioethanol plant in Halle sold 158 thousand gallons of this fuel in 2017, which increased the region's budget by 23 million Euros [16].

In general, the priority areas for the effectiveness of the development of ecological and economic competitiveness of the regions of Germany are based on the following set principles of economic development and the dynamics of regional indicators of the postulates:

1) monitoring, control and analysis of statistics data on the development of economic sectors, ecological and economic development with the purpose of formulation and usage at the subnational level of adapted supporting management technologies;

2) active recycling and using utility waste in all business and manufacturing sectors;

3) using of historically formed and geographically-natural ecological and economic competitive advantages, stimulating the sale of ecological products to the regions which do not have it, for the economic equalization of territories;

4) implementation of regional ecological and economic programs aimed at integrated use of territorial competitive advantages and enhancement of their ecological potential in order to maintain a long-term effective development;

5) the existence of a unified development strategy for all regions, based on the synergism of economic development and the environmental priority of the national idea "Nature must always remain nature" [17];

6) high level of environmental education and culture, which ensures the behavior of the population and business structures, despite of minimal state support and maintaining ecological and economic competitiveness.

The ecological and economic activity of most regions in developed countries is based on a cluster system of organization of ecological productions.

One of the most famous European clusters in which environmental problems are solved is AXELERA cluster, which includes 322 organizations in France, Spain, and England [18].

Axelera is a cluster operating at the crossroads of the chemical, environmental and energy sectors, supports innovative and international initiatives to develop the competitiveness of industrial companies. Based in Lyon (France), a global center for the chemical industry, Axelera has built a strong foundation in France in the Auvergne-RhôneAlpes region. As a part of this cluster, 85 large companies, 120 small and medium-sized 
businesses and 55 scientific organizations are solving issues in five strategic areas: restoration of raw materials, activity of eco-efficient factories, chemicals for industrial activity, recycling, conservation and restoration of natural resources. 286 environmental (R\&D) projects are certified by Axelera and funded since cluster creation; the total amount of received funds was 800 million Euros [19].

In the United States, the Energy Cluster creates up to $5.7 \%$ of workplaces in the national economy. Almost $8 \%$ of US counties specialize in renewable energy [20].

Conclusions and prospects for further researches. Priority directions of efficiency of development of ecological and economic competitiveness of regions in developed countries of the world are characterized by:

- firstly, the slight differentiation of the ecological and economic competitiveness of the regions in certain countries, the territories try to support already existing successful projects often on the basis of cluster cooperation;

- secondly, the support of state and local authorities for eco-innovation as an important basis for the formation and development of ecological and economic competitiveness;

- thirdly, the active scientific component of ecological and economic competitiveness, combined with minimal state intervention in the process of formation and implementation of eco-economic innovations and the successful use of ecological and economic competitive advantages, provides a platform for the development of ecological and economic programs for regional development;

- fourthly, the availability of environmental education and culture, which is the basis of all activities and ensures the appropriate behavior of the population and business structures, as well as the ecological and economic competitiveness of the regions.

The prospects for further research in this area will be related to the developmentof the methodology, which will allow to determine the scope of these regulators for managing the ecological and economic competitiveness of the region through tangible mutual effects of the economic and environmental subsystems.It is necessary to add a social block to implement the mechanism in the program of ecological and economic development of the region. This mechanism integrates environmental and economic blocks of the program in the application of general and region-specific strategic, tactical and operational innovation regulators, which allows to take into account the environmental specificity, social and economic development of the region.

\section{References}

1. Lovelock, James. Gaia (2000). A New Look at Life on Earth. (3d ed.). England: Oxford University Press

2. Le Roy, Edouard Louis Emmanuel Julien (1928). Les origines humaines et l'évolution de l'intelligence. Paris: Boivin [in French].

3. Chesnokov, B.C., Prokopenko, E.E., \& P'er Tejjar de Sharden (2005). O cheloveke, noosfere i kosmose [About man, the noosphere and space]. Zhurnal «Kul'tura i vremja»-Journal «Culture and Time», 3 [in Russian].

4. Onyschenko, O.S., Bieliaieva, L.V., Dziubych, S.A., Novos'olova, L.S., Omel'chuk, V.Yu., Ustynovs'kyj, D.V. (2012). Bibliography of works of V.I Vernadsky. Literature about life and activity. O.S. Onyschenko (Ed.). (Vol.10). Kyiv: Komisiia NAN Ukrainy z nauk. spadschyny akad. V.I. Vernads'koho, Nats. b-ka Ukrainy imeni V. I. Vernads'koho.

5. Gofman, K.G. (1975). Jekonomicheskaja ocenka prirodnyh resursov i izderzhek zagrjaznenija okruzhajushhej sredy (voprosy teorii $i$ metodologii). [Economic assessment of natural resources and costs of environmental pollution (theory and methodology)]. M.: VINITI [in Russian].

6. Informatsijno-analitychnyj portal EES EAES. Enerhetychna statystyka [EES EAES Information and Analysis Portal. Energy statistics]. eeseaec.org. Retrieved from http://www.eeseaec.org/contact-us [in Ukrainian]. 
7. Sajt Heohrafichnyj dovidnyk [Website Geographic Directory]. (2019). merkator.org.ua. Retrieved from http://merkator.org.ua/dovidnyk/spysok-krajin-za-naselennam [in Ukrainian].

8. State Total Energy Rankings. (2017). eia.gov. Retrieved from https://www.eia.gov/state/?sid=US [in English].

9. Coal International, 5, 191-193, 195-197. mqworld.com. Retrieved from https://mqworld.com/onlinejournals/ [in English].

10. Ukrains'ka vitroenerhetychna asotsiatsiia. Svitivyi Proryv Ofshornoy Vitroenertyky [Ukrainian Wind Energy Association. THE WORLD BREAK OF OFFSHORE WIND POWER]. uwea.com.ua. Retrieved from http://uwea.com.ua/ua/article/mirovoj-proryv-offshornoj-vetroenergetiki/ [in Ukrainian].

11. Ofitsijnyj sajt Derzhavne ahentstvo z enerhoefektyvnosti ta enerhozberezhennia [Official site of the State Agency for Energy Efficiency and Energy Conservation]. saee.gov.ua. Retrieved from http://www.saee.gov.ua/uk/ae/windenergy/ [in Ukrainian].

12. WIRTSCHAFT.NRW. Innovation. Digitalisierung. Energie. wirtschaft.nrw. Retrieved from https://www.wirtschaft.nrw/wirtschaft [in German].

13. Ofitsijnyj sajt ministerstva ekonomiky ta rehional'noho rozvytku Bavarii [The official website of the Bavarian Ministry of Economy and Regional Development]. (n.d.). stmwi.bayern.de. Retrieved from https://www.stmwi.bayern.de/energie-rohstoffe/beratung-forschung/ [in German].

14. Ofitsijnyj sajt Ministerstva ekonomiky, nauky ta otsyfruvannia Zemli Saksoniia-Anhal't [The official website of the Ministry of Economy, Science and Digitization of the Saxony-Anhalt]. (n.d.). mw.sachsenanhalt.de. Retrieved from https://mw.sachsen-anhalt.de/service/publikationen/\#c170645 [in German].

15. Portal Innovatsii [Innovation portal]. (2017). yитри.com. Retrieved from https://www.yumpu.com/de/document/view/59624968/hier-jetztimpulsmagazin-ausgabe-02-2017 [in German].

16. Internetresurs. Federal'na asotsiatsiia nimets'koi bioetanolovoi promyslovosti [Internet resource. Federal Association of German Bioethanol Industry]. bdbe.de. Retrieved from https://www.bdbe.de/oekologie [in German].

17. Manifest sotsial'noi ta ekolohichnoi transformatsii. 30-j Federal'nyj konhres "Novyj sotsial'nyj dohovir" [Manifesto of social and environmental transformation. 30th Federal Congress "New Social Treaty"]. naturfreunde.de. Retrieved from https://www.naturfreunde.de/manifest-transformation [in German].

18. European claster collaboranion platform (n.d.). axelera.org. Retrieved from https://www.axelera.org/en/key-figures/ [in English].

19. Site Axelera. Key figures. axelera.org. Retrieved from https://www.axelera.org/en/key-figures/ [in English].

20. Regional Clusters in a Global World. (n.d.). statsamerica.org. Retrieved from https://www.statsamerica.org/innovation/reports/trifold_single_pages.pdf [in English].

Н.О. Андрусяк, доц., канд. екон. наук

Черкаський національний університет імені Богдана Хмельницького, м Черкаси, Україна

\section{Пріоритетні напрями розвитку еколого-економічної конкурентоспроможності регіонів розвинених країн}

Статтю присвячено огляду пріоритетних напрямів еколого-економічної конкурентоспроможності регіонів окремих розвинених країн. Метою дослідження $є$ висвітлення питання саме пріоритетності еколого-економічної конкурентоспроможності регіонів розвинених країн, які досліджені не повністю в силу розвитку науково-технічного прогресу, потужності й різноспрямованості еколого-економічних трансформацій у світі та їх наслідків.

В результаті досліджень виявлено екологічні види економічної діяльності, яким віддають перевагу регіони цих країн. Узагальнено дослідження пріоритетних напрямів ефективності розвитку еколого-економічної конкурентоспроможності регіонів США та Німеччини та визначено, що в основі еколого-економічної діяльності більшості регіонів у розвинених країнах лежить кластерна система організації екологічних виробництв. Обгрунтовано, що за сучасних умов еколого-економічного розвитку наявні запаси ресурсів у регіонах не $є$ визначаючими для розвитку конкретних галузей, розвиток залежить від новітніх науково-технічних розробок у певній сфері. Виробництво екологічно нейтральної та екологічно спрямованої продукції дозволяє багатьом регіонам зменшити залежність від невідновних ресурсів без зниження ефективності результатів господарювання.

Пріоритетним напрямам ефективності розвитку еколого-економічної конкурентоспроможності регіонів у розвинених країнах світу характерні: по-перше, незначна диференціація еколого-економічної конкурентоспроможності регіонів в окремих країнах, території намагаються підтримати вже наявні успішні проекти часто на основі кластерної співпраці; по-друге, підтримка державною та місцевою владами екологічних інновацій як важлива основа формування та розвитку еколого-економічної конкурентоспроможності; по-третє, активна наукова складова еколого-економічної 
конкурентоспроможності у поєднанні з мінімальним державним втручанням в процес формування i впровадження еколого-економічних інновацій та вдалим використанням еколого-економічних конкурентних переваг забезпечує платформу для розробки еколого-економічних програм розвитку регіонів; по-четверте, наявність екологічної освіти і культури, що є основою усіх видів діяльності та забезпечує відповідну поведінку населення й підприємницьких структур та еколого-економічну конкурентоспроможність регіонів.

регіон, екологічна та економічна конкурентоспроможність, світовий досвід, екологічна продукція, національна та місцева підтримка, кластерна співпраця

Одержано (Received) 15.05.2019

Прореиензовано (Reviewed) 22.05.2019

Прийнято до друку (Approved) 04.06.2019

УДК 364.254:332.12

JEL Classification: Q57

DOI: https://doi.org/10.32515/2663-1636.2019.2(35).62-69

В.С. Чубань, доц., канд. екон. наук

Ю.М. Горбаченко, доц., канд. істор. наук

Черкаський інститут пожежної безпеки імені Героїв Чорнобиля НУЦЗУ, м. Черкаси, Украӥна

\section{Еколого-економічні наслідки пожеж у природних екосистемах}

У статті проаналізовано сучасні тенденції виникнення пожеж у природних екосистемах, які призводять до істотних економічних втрат і негативних екологічних наслідків та $є$ небезпечним явищем у довкіллі, що в свою чергу призводить до дестабілізації сталого розвитку економіки країни. Визначено проблеми забезпечення належного рівня захисту у природних екосистемах від пожеж та їх негативних наслідків, що полягає у комплексному поетапному вирішенні проблемних питань належного фінансування пожежно-рятувальних підрозділів, в тому числі за рахунок додаткового фінансування за рахунок місцевого бюджету

фінансування пожежно-рятувальних підрозділів, бюджет, еколого-економічні збитки, пожежі в екосистемах

В.С. Чубань, доц., канд. экон. наук

Ю.Н. Горбаченко, доц., канд. истор. наук

Черкасский институт пожарной безопасности имени Героев Чернобыля НУГЗУ, г. Черкассы, Украина

Эколого-экономические последствия пожаров в природных экосистемах

В статье проанализированы современные тенденции возникновения пожаров в природных экосистемах, которые приводят к существенным экономическим потерям и негативным экологическим последствиям и являются опасным явлением в окружающей среде, что в свою очередь приводит к дестабилизации устойчивого развития экономики страны. Определены проблемы обеспечения надлежащего уровня защиты в природных экосистемах от пожаров и их негативных последствий, которые заключаются в комплексном поэтапном решении проблемных вопросов надлежащего финансирования пожарно-спасательных подразделений, в том числе за счет дополнительного финансирования за счет местного бюджета.

финансирование пожарно-спасательных подразделений, бюджет, эколого-экономический ущерб, пожары в экосистемах

Постановка проблеми. Сучасний період розвитку суспільства характеризується все більшими протиріччями між людиною і навколишнім середовищем. Вони приводять до виникнення стихійних лих, катастроф, пожеж і надзвичайних ситуацій, наслідки яких можуть бути жахливими.

Наприклад, ліси забезпечують умови для існування одних 3 найбагатших за біорізноманіттям екосистем на Землі, а також умови існування для 90 \% видів, яким загрожує небезпека зникнення. Біорізноманіття має надзвичайно велике значення для практичного життя людства, забезпечуючи сировину для ліків та рослинних екстрактів.

(C) В.С. Чубань, Ю.М. Горбаченко, 2019 